\title{
Humus Components and Soil Biogenic Structures in Norway Spruce Ecosystems
}

\author{
Paola Galvan \\ Centro di Ecologia Alpina \\ Fondazione Edmund Mach \\ 38100 Viote del Monte Bondone (Trento) \\ Italy
}

\section{Jean-François Ponge* \\ Muséum National d'Histoire Naturelle \\ CNRS UMR 7179 \\ 4 avenue du Petit-Chateau \\ 91800 Brunoy \\ France}

\section{Silvia Chersich}

Università degli Studi di Milano-Bicocca

Dipartimento di Scienze dell'Ambiente e del

Territorio

20126 Milano

Italy

and

Centro di Ecologia Alpina

Fondazione Edmund Mach

38100 Viote del Monte Bondone (Trento) Italy

\author{
Augusto Zanella \\ Università di Padova \\ Facoltà di Agraria \\ Dip. TeSAF \\ Viale dell'Università \\ 2335020 Legnaro (PD) \\ Italy
}

Whether the structure of $\mathrm{Oa}$ and $\mathrm{A}$ horizons varies according to animal activity is still a matter of conjecture, especially in amphi, a humus form with mixed features of mull and moder, which has been described in environments with strong seasonal contrasts. The $\mathrm{Oa}$ and $\mathrm{A}$ horizons of spruce [Picea abies (L.) Karst.] coniferous forests of the Province of Trento (Italy) were sampled in six sites with a total of 134 humus profiles along transect lines, embracing the variety of parent rocks, climate, and vegetation conditions that prevail at the upper montane level in this region. The distribution of humus components (plant debris, roots, animal feces, minerals) was assessed by an optical method and analyzed with correspondence analysis (CA). Moder humus forms were characterized by enchytraeid activity, with concomitant deposition of organic and mineral-organic feces in $\mathrm{Oa}$ and $\mathrm{A}$ horizons, respectively. Conversely, amphis were characterized by the concomitant deposition of organic and mineral-organic earthworm feces in $\mathrm{Oa}$ and $\mathrm{A}$ horizons, respectively. We conclude that $\mathrm{Oa}$ and $\mathrm{A}$ horizons of moders and amphis differed only quantitatively in the content of mineral matter in animal feces. The fine-grained mineral-organic structure that is mostly found in the A horizon of amphis results from the alimentary activity of small epigeic earthworms that mix organic matter with mineral matter, like anecic earthworms do in mulls.

Abbreviations: AN, Acid North; AS, Acid South; BN, Basic North; BS, Basic South; CA, correspondence analysis; IN, Intermediate North; IS, Intermediate South.
$\mathrm{C}$ oniferous forests, in particular Norway spruce stands, are known for the accumulation of organic matter in thick litter horizons (Ovington, 1954; Nihlgård, 1971). Space-fortime substitution (Pickett, 1989) studies on indigenous multilayered forest stands showed that this accumulation occurs during the pole stage of tree development and is reversible under

Soil Sci. Soc. Am. J. 72:548-557

doi:10.2136/sssaj2006.0317

Received 5 Sept. 2006.

*Corresponding author (ponge@mnhn.fr).

(c) Soil Science Society of America

677 S. Segoe Rd. Madison WI 53711 USA

All rights reserved. No part of this periodical may be reproduced or transmitted in any form or by any means, electronic or mechanical, including photocopying, recording, or any information storage and retrieval system, without permission in writing from the publisher. Permission for printing and for reprinting the material contained herein has been obtained by the publisher. mature trees (Bernier and Ponge, 1994; Bernier, 1996; Sagot et al., 1999), whereas studies dealing with even-aged plantations show a continuous increase until mature trees are cut (Chauvat et al., 2007). The influence of stand development on soil nutrient pools and decomposer communities (Nilsson et al., 1982; Miller, 1984; Ulrich, 1994) and the patchy structure of coniferous forests (Bernier and Ponge, 1998; Ponge et al., 1998; Ponge, 1999a) are thought to be responsible for the observed patterns.

Moders, mulls, and mors are the dominant humus forms in the topsoil of forest ecosystems (Ponge, 2003). They differ by the distribution of organic and mineral-organic horizons, called Oi (organic, slightly decomposed), Oe (organic, moderately decomposed), $\mathrm{Oa}$ (organic, highly decomposed), and A (mineral mixed with humus, decomposed) in the most complete case (Schaetzl and Anderson, 2005). Mulls are characterized by a crumby structure (mostly created by earthworms) in the mineral-organic A horizon. Moders are characterized by the accu- 
mulation of organic invertebrate feces in the overlying Oa horizon. Amphimulls (Brêthes et al., 1995; Ponge et al., 2002; Galvan et al., 2005), now called amphis (Jabiol et al., 2004; Graefe and Beylich, 2006), exhibit mixed features of moders and mulls, and are widely represented in Mediterranean as well as mountain and tropical forest ecosystems (Loranger et al., 2003; Jabiol et al., 2004). They are characterized by a crumby structure in the mineral-organic A horizon, like in mulls, and by the concomitant accumulation of organic invertebrate feces in the overlying Oa horizon, like in moders. The objective of the current study was to investigate whether the two horizons should be considered as two largely independent compartments of the topsoil, or whether the same kind of animal activity could explain their common occurrence. In other words, when lumbricids (typical of mulls) are present, are they able to process the organic matter accumulated in Oa horizons? When earthworms are replaced by animals of a smaller size, such as enchytraeids (typical of moders), does the latter animal group create the structures observed in the A horizon? Is there any influence of the age of trees on these patterns? Answering these questions may improve our knowledge of the biological processes by which organic matter may accumulate or not in mountain and boreal coniferous forests, known worldwide as active carbon sinks (Vetter et al., 2005).

\section{MATERIALS AND METHODS Study Sites}

Six Norway spruce sites were chosen in the northern Italian Alps, Province of Trento, embracing the wide range of environmental conditions (substrate, elevation, aspect, rainfall) that prevail in the western European part of its present-day natural distribution area (Scotti et al., 2000).

Three geological substrates (referred to as Acid, Intermediate, and Basic), each with two aspects (North, South), were selected at an altitude ranging from 1650 to $1870 \mathrm{~m}$, that is, at the upper montane level (Odasso, 2002) (Fig. 1). Table 1 summarizes climatic and geological fea-

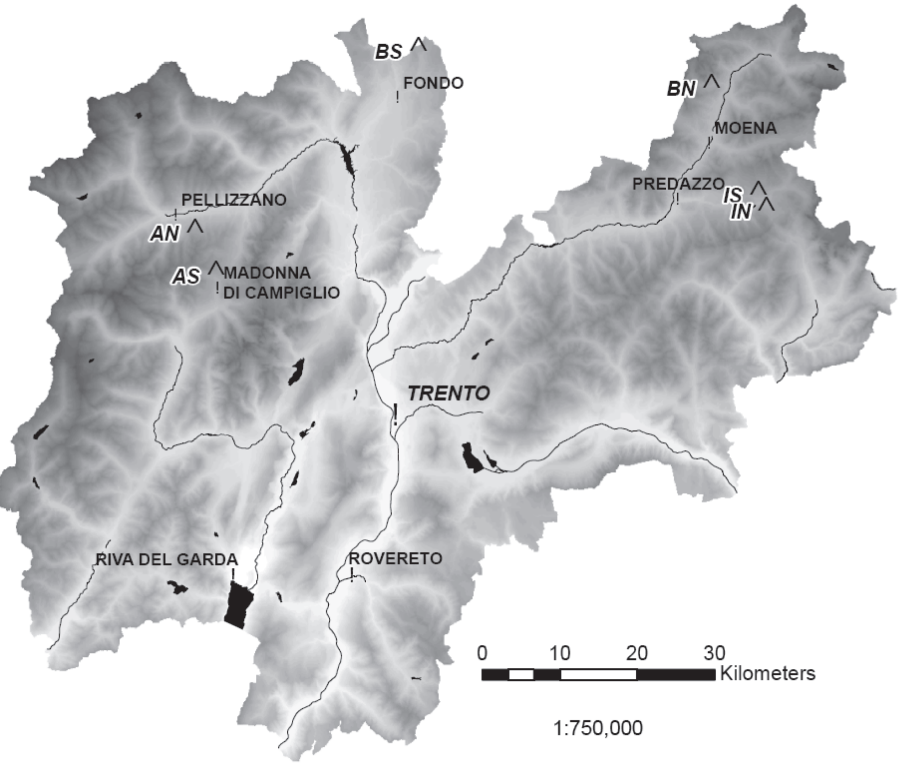

Fig. 1. Geographical position of the six study sites Acid North (AN), Acid South (AS), Intermediate North (IN), Intermediate South (IS), Basic North (BN), and Basic South (BS) in the Province of Trento.

tures of the six sites. All study sites were managed with natural regeneration (selection system) as the prevailing system for successive croppings. At each site the selected transect crossed a mosaic of trees or clumps of trees of different ages.

\section{Sampling}

A transect line was drawn in six spruce stands, representing a wide variety of environmental conditions at the site. At each site the transect crossed the widest possible variation in vegetation, in particular the four main stand developmental phases: 'gap', 'regeneration', 'intermediate', and 'mature'. Oa and A horizons were sampled every 3 $\mathrm{m}$, thus totalling 134 samples (19 in AN, 27 in AS, 18 in IN, 25 in IS, 22 in BN, 23 in BS). They were analyzed microscopically according to the 'small volume' method (Sadaka and Ponge, 2003). The sampling method for humus profiles was described in detail by Bernier et al.

Table 1. Main features of the six study sites. Soil types according to World Reference Base (Bridges et al., 1998). Humus forms according to Brêthes et al. (1995).

\begin{tabular}{|c|c|c|c|c|c|c|}
\hline Site code & AN & AS & IN & IS & BN & BS \\
\hline Site name & Pellizzano & $\begin{array}{l}\text { Madonna di } \\
\text { Campiglio }\end{array}$ & Paneveggio & Paneveggio & Gardeccia & Fondo \\
\hline Soil types & $\begin{array}{l}\text { Podzols, Histosols, } \\
\text { Umbrisols }\end{array}$ & $\begin{array}{l}\text { Umbrisols, } \\
\text { Cambisols, } \\
\text { Podzols }\end{array}$ & $\begin{array}{l}\text { Cambisols, } \\
\text { Podzols, Leptosols }\end{array}$ & $\begin{array}{l}\text { Cambisols, } \\
\text { Podzols, Regosols }\end{array}$ & $\begin{array}{l}\text { Cambisols, } \\
\text { Regosols }\end{array}$ & $\begin{array}{l}\text { Cambisols, } \\
\text { Leptosols, } \\
\text { Regosols }\end{array}$ \\
\hline Humus forms & $\begin{array}{l}\text { Mor, dysmoder, } \\
\text { dysmull, } \\
\text { amphimull }\end{array}$ & $\begin{array}{l}\text { Mor, dysmoder, } \\
\text { eumoder, } \\
\text { oligomull, } \\
\text { amphimull }\end{array}$ & $\begin{array}{l}\text { Mor, dysmoder, } \\
\text { dysmull, } \\
\text { amphimull }\end{array}$ & $\begin{array}{l}\text { Mor, dysmoder, } \\
\text { dysmull, } \\
\text { oligomull, } \\
\text { amphimull }\end{array}$ & $\begin{array}{l}\text { Eumoder, dysmull, } \\
\text { oligomull, } \\
\text { amphimull }\end{array}$ & $\begin{array}{l}\text { Eumoder, dysmull, } \\
\text { mesomull, } \\
\text { amphimull }\end{array}$ \\
\hline Parent material & $\begin{array}{l}\text { Acid boulder clay } \\
\text { overlying granitic } \\
\text { stones }\end{array}$ & $\begin{array}{l}\text { Plutonic granite } \\
\text { often covered by } \\
\text { late-Wurm silica- } \\
\text { rich deposits }\end{array}$ & Permian rhyolite & $\begin{array}{l}\text { Mixed volcanic/ } \\
\text { dolomitic moraine }\end{array}$ & $\begin{array}{l}\text { Dolomitic moraine } \\
\text { with granitic } \\
\text { erratic boulders }\end{array}$ & $\begin{array}{l}\text { Dolomitic moraine } \\
\text { with granitic } \\
\text { erratic boulders }\end{array}$ \\
\hline Exposure & North & South & North & South & North & South \\
\hline Elevation, m & $1650-1870$ & 1720-1865 & $1660-1780$ & 1620-1818 & 1620-1820 & $1640-1690$ \\
\hline Mean slope, \% & 27 & 32 & $16 \%$ & 15 & 18 & 15 \\
\hline Mean annual temperature, ${ }^{\circ} \mathrm{C}$ & 4.2 & 4.0 & 9.2 & 4.4 & 4.3 & 5.3 \\
\hline Mean annual rainfall, $\mathrm{mm}$ & 962 & 1303 & 782 & 1103 & 1049 & 863 \\
\hline
\end{tabular}


(1993) and Bernier and Ponge (1994). A block, $25 \mathrm{~cm}^{2}$ in area and with such a depth as to reach the B horizon, was prepared directly in the field with a sharp knife. Each Oa and A horizon was isolated and fixed immediately in $95 \%(\mathrm{v} / \mathrm{v})$ ethyl alcohol in a $400-\mathrm{mL}$ hermetic seal polypropylene box, with as little disturbance as possible, then transported to the laboratory until analysis. Several layers may be sampled separately wihin the same Oa or A horizon, providing they exhibit clear differences (to the naked eye) in their apparent composition.

\section{Laboratory Analyses}

In the laboratory, each sampled horizon was studied under a dissecting microscope, after spreading it out as gently as possible in a 15-cm diam. Petri dish, filled with $95 \%$ (v/v) ethyl alcohol. The different components were quantified by the point-count method first described by Jongerius (1963) for the study of soil sections. Under the dissecting microscope, humus components under each point of a transparent film with a 157 -points grid were recorded, resulting in a

\section{Table 2. List of categories used to describe the composition of $\mathrm{Oa}$ and $\mathrm{A}$ horizons.}

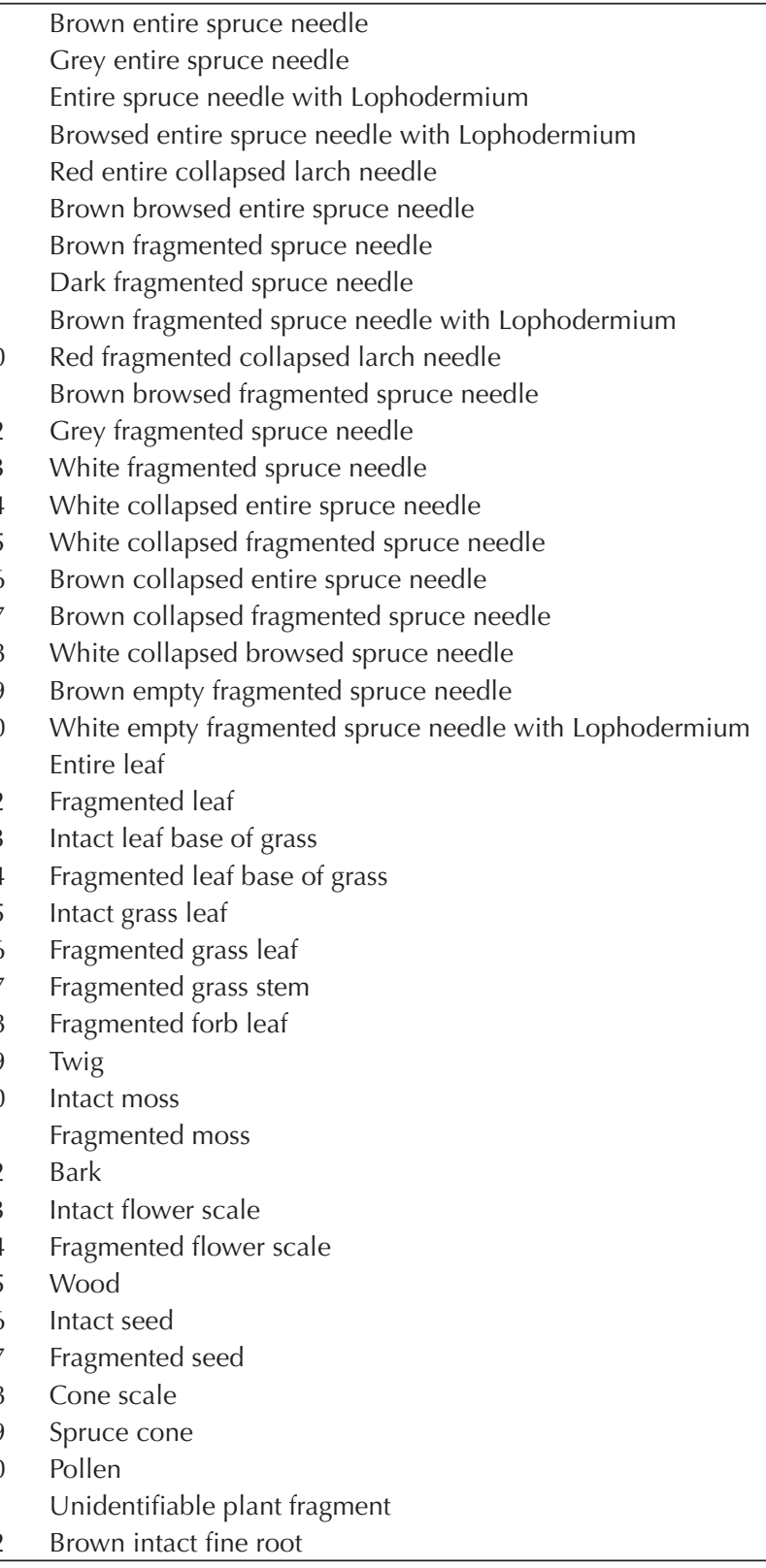

table showing the distribution (percentage volume) of 84 categories of humus (Table 2) among the 375 layers investigated. In a given layer the relative volume of each component of the soil matrix was estimated by the number of times it has been recorded divided by the total number of points of the grid.

Chemical analyses were performed on a selection of soil samples taken along each transect line. Only data for the top $1 \mathrm{~cm}$ of the A horizon were shown (Table 3). Organic $\mathrm{C}$ and total $\mathrm{N}$ were measured in 10 to $20 \mathrm{mg}$ of dried soil. Air-dried soil samples were sieved to $200 \mu \mathrm{m}$ and homogenized, then $\mathrm{C}$ and $\mathrm{N}$ were dosed in a CHN atomic analyzer (PerkinElmer CHNS/O Analyzer 2400 Series II, PerkinElmer, Waltham, MA). Calcium carbonates were removed with $\mathrm{HCl}$ before analysis. Soil $\mathrm{pH}-\mathrm{H}_{2} \mathrm{O}$ and $\mathrm{pH}-\mathrm{KCl}$ were measured with a glass-electrode in a 1:2.5 w/v suspension of soil in deionized water or $\mathrm{KCl}$ solution, mixed for $2 \mathrm{~h}, \mathrm{pH}$ being measured on the supernatant. The cation-exchange capacity (CEC) was measured in $\mathrm{BaCl}_{2}(\mathrm{pH}$ 8.2). A successive addition of $\mathrm{MgSO}_{4}$ allowed the complete exchange between $\mathrm{Ba}$ and $\mathrm{Mg}$, followed by analysis of supernatant for $\mathrm{Mg}$ by

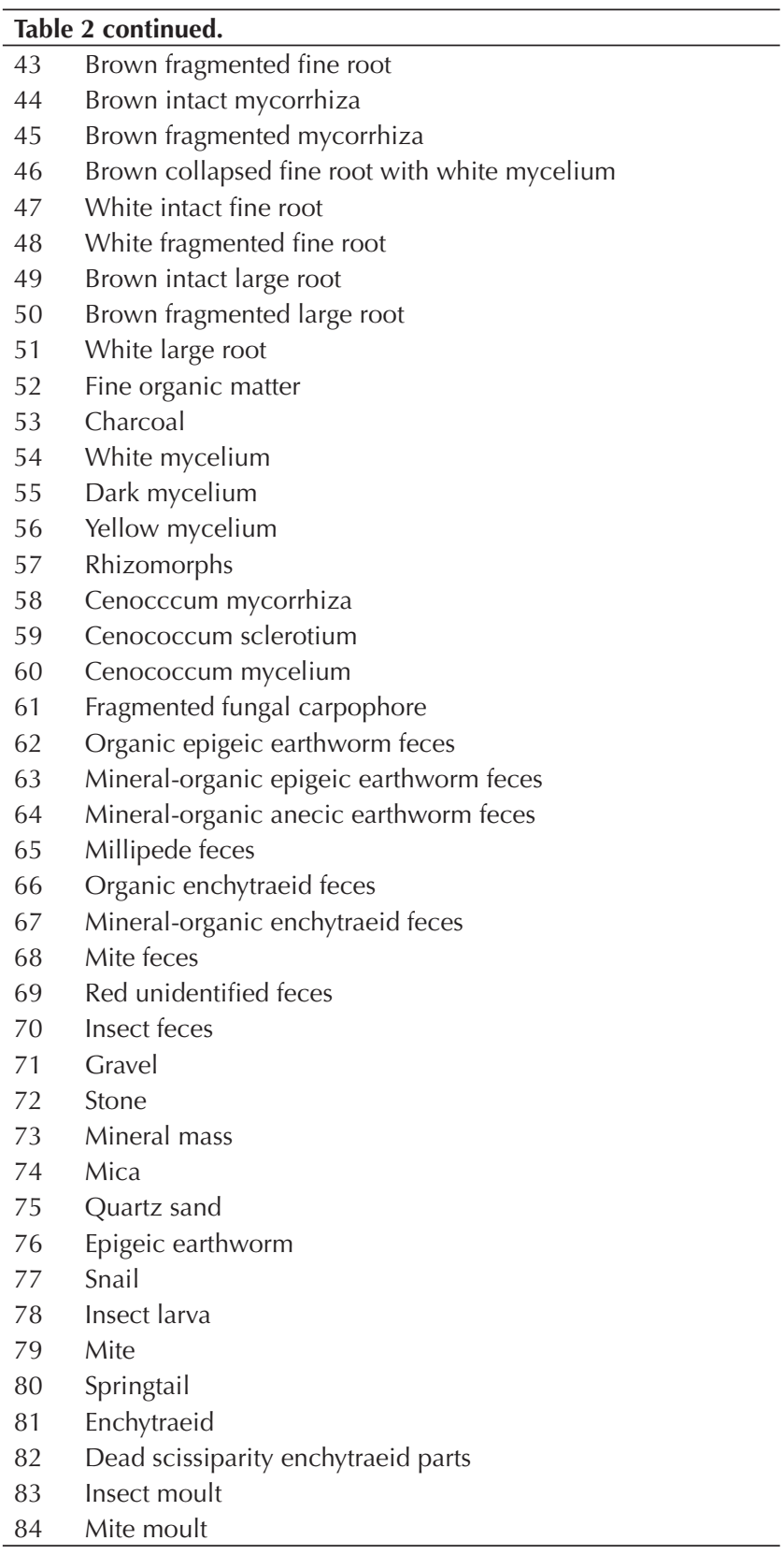


Table 3. Main physicochemical features of selected samples of $A$ horizons in the six study sites (mean \pm SE).

\begin{tabular}{|c|c|c|c|c|c|c|}
\hline \multirow[b]{3}{*}{ Chemical analyses } & \multicolumn{6}{|c|}{ Site code } \\
\hline & AN & AS & IN & IS & BN & BS \\
\hline & 8 samples & 15 samples & 11 samples & 15 samples & 17 samples & 18 samples \\
\hline Organic C $\left(\mathrm{g} \mathrm{kg}^{-1}\right)$ & $186 \pm 36$ & $200 \pm 16$ & $126 \pm 21$ & $124 \pm 19$ & $97 \pm 9$ & $135 \pm 20$ \\
\hline Total N $\left(\mathrm{g} \mathrm{kg}^{-1}\right)$ & $10.2 \pm 2.1$ & $9.9 \pm 0.7$ & $7.5 \pm 1.4$ & $6.0 \pm 0.8$ & $6.0 \pm 0.4$ & $8.0 \pm 0.9$ \\
\hline $\mathrm{C} / \mathrm{N}$ & $18.6 \pm 0.9$ & $20.3 \pm 0.5$ & $17.2 \pm 0.9$ & $20.2 \pm 0.8$ & $16.2 \pm 0.8$ & $16.5 \pm 0.8$ \\
\hline Carbonates (g kg-1) & - & - & $3.6 \pm 0.1$ & - & $23.0 \pm 4.3$ & $24.4 \pm 4.1$ \\
\hline $\mathrm{pH} \mathrm{KCl}$ & $3.4 \pm 0.1$ & $3.6 \pm 0.1$ & $4.3 \pm 0.1$ & $4.2 \pm 0.3$ & $5.8 \pm 0.2$ & $5.5 \pm 0.4$ \\
\hline $\mathrm{pH} \mathrm{H} \mathrm{H}_{2} \mathrm{O}$ & $4.2 \pm 0.1$ & $4.3 \pm 0.1$ & $4.2 \pm 0.1$ & $5.1 \pm 0.2$ & $6.3 \pm 0.2$ & $6.2 \pm 0.3$ \\
\hline CEC pH soil $\left(\mathrm{cmol} \mathrm{kg}^{-1}\right)$ & $98 \pm 13$ & $92 \pm 4$ & $63 \pm 5$ & $86 \pm 8$ & $85 \pm 4$ & $90 \pm 9$ \\
\hline CEC pH $7\left(\mathrm{cmol} \mathrm{kg}^{-1}\right)$ & $68 \pm 6$ & $51 \pm 6$ & $44 \pm 4$ & $57 \pm 7$ & $57 \pm 3$ & $64 \pm 6$ \\
\hline Exchangeable $\mathrm{Ca}\left(\mathrm{cmol} \mathrm{kg}^{-1}\right)$ & $3.7 \pm 1.6$ & $10.4 \pm 1.4$ & $5.2 \pm 1.2$ & $28.6 \pm 8.5$ & $46.0 \pm 3.4$ & $41.6 \pm 7.2$ \\
\hline Exchangeable $\mathrm{Mg}\left(\mathrm{cmol} \mathrm{kg}^{-1}\right)$ & $1.9 \pm 1.3$ & $1.6 \pm 0.2$ & $0.8 \pm 0.1$ & $5.8 \pm 1.9$ & $13.4 \pm 1.3$ & $13.5 \pm 2.1$ \\
\hline Exchangeable $\mathrm{K}\left(\mathrm{cmol} \mathrm{kg}^{-1}\right)$ & $0.5 \pm 0.2$ & $1.0 \pm 0.1$ & $0.7 \pm 0.1$ & $0.7 \pm 0.1$ & $0.6 \pm 0.1$ & $0.7 \pm 0.1$ \\
\hline Base saturation (\%) & $5.2 \pm 1.5$ & $13.8 \pm 2.1$ & $10.1 \pm 1.7$ & $38.4 \pm 8.5$ & $70.6 \pm 4.2$ & $62.2 \pm 9.6$ \\
\hline Exchangeable acidity $\left(\mathrm{cmol} \mathrm{kg}^{-1}\right)$ & $11.2 \pm 0.6$ & $7.3 \pm 0.9$ & $7.0 \pm 1.8$ & $3.6 \pm 1.2$ & $0.3 \pm 0.02$ & $4.2 \pm 0.7$ \\
\hline Exchangeable $\mathrm{Al}^{+++}\left(\mathrm{cmol} \mathrm{kg}^{-1}\right)$ & $8.9 \pm 0.7$ & $4.7 \pm 0.7$ & $5.3 \pm 1.5$ & $2.8 \pm 0.9$ & $0.2 \pm 0.02$ & $2.8 \pm 0.5$ \\
\hline Exchangeable $\mathrm{H}^{+}\left(\mathrm{cmol} \mathrm{kg}^{-1}\right)$ & $2.3 \pm 0.2$ & $2.5 \pm 0.3$ & $1.6 \pm 0.4$ & $0.8 \pm 0.2$ & $0.1 \pm 0.01$ & $1.4 \pm 0.4$ \\
\hline Total acidity $\left(\mathrm{cmol} \mathrm{kg}^{-1}\right)$ & $121 \pm 8$ & $99 \pm 7$ & $54 \pm 7$ & $34 \pm 6$ & $25 \pm 3$ & $54 \pm 11$ \\
\hline Particle size distribution & 5 samples & 8 samples & 8 samples & 8 samples & 8 samples & 8 samples \\
\hline Coarse sand $\left(\mathrm{g} \mathrm{kg}^{-1}\right)$ & $175 \pm 33$ & $307 \pm 35$ & $330 \pm 53$ & $190 \pm 41$ & $35 \pm 4$ & $61 \pm 13$ \\
\hline Fine sand $\left(\mathrm{g} \mathrm{kg}^{-1}\right)$ & $169 \pm 12$ & $233 \pm 20$ & $162 \pm 29$ & $148 \pm 15$ & $132 \pm 8$ & $145 \pm 13$ \\
\hline Coarse silt $\left(\mathrm{g} \mathrm{kg}^{-1}\right)$ & $156 \pm 15$ & $136 \pm 11$ & $102 \pm 14$ & $146 \pm 21$ & $230 \pm 20$ & $140 \pm 11$ \\
\hline Fine silt $\left(\mathrm{g} \mathrm{kg}^{-1}\right)$ & $262 \pm 19$ & $201 \pm 13$ & $232 \pm 29$ & $252 \pm 11$ & $391 \pm 19$ & $334 \pm 17$ \\
\hline Clay $\left(\mathrm{g} \mathrm{kg}^{-1}\right)$ & $238 \pm 32$ & $123 \pm 13$ & $174 \pm 15$ & $264 \pm 43$ & $211 \pm 12$ & $321 \pm 9$ \\
\hline
\end{tabular}

complexometry (West, 1969). Exchangeable $\mathrm{Ca}^{2+}, \mathrm{Mg}^{2+}$, and $\mathrm{K}^{+}$were determined by atomic absorption spectrophotometry (PerkinElmer Analyst 200, PerkinElmer, Waltham, MA). Base saturation was calculated as the ratio $\Sigma\left(\right.$ exchangeable $\left.\mathrm{Ca}^{2+}, \mathrm{Mg}^{2+}, \mathrm{K}^{+}\right) / \mathrm{CEC} \times 100$. Total acidity was determined by titrating with $\mathrm{HCl}$ the solution obtained by treating the soil sample with $\mathrm{BaCl}_{2}$, buffered at $\mathrm{pH}$ 8.2. To obtain exchangeable acidity, $\mathrm{KCl}$ was added to the soil sample and the solution was titrated with $\mathrm{NaOH}$. By adding $\mathrm{NaF}(10 \mathrm{~mL})$ to this solution and titrating with $\mathrm{HCl}$ we obtained exchangeable $\mathrm{Al}^{+++}$. $\mathrm{H}^{+}$was calculated by subtracting exchangeable $\mathrm{Al}$ from exchangeable acidity.

\section{Statistical Treatment}

Correspondence analysis or CA (Greenacre, 1984) was used to see whether clusters with similar distributions of humus components could be distinguished within the whole set of layers. Raw data (percentage volumes of categories) were considered as active (main) variables and were not transformed before analysis. The six sites (AN, AS, IN, IS, BN, BS) and the Oa and A horizons were included as passive (additional) variables, to show whether there was a correspondence between the horizons, the sites and the animal groups.

The product-moment correlation coefficient (Sokal and Rohlf, 1995) was used to test the correlation between either the same humus component sampled in different horizons, or between different humus components sampled in the same horizons. When several successive layers of the same horizon ( $\mathrm{Oa}$ or A) had been sampled, they were averaged by weighting them according to thickness.

Multivariate statistics and other statistical treatment of the data were performed using the Statbox Pro software package (Grimmersoft, France).

\section{RESULTS}

\section{Were There Different Kinds of Oa and A Horizons?}

The 84 categories of humus components identified under the dissecting microscope are listed in Table 2, together with their numerical codes in the CA. They were comprised mainly of plant debris (mostly spruce needles and roots but other plant parts were identified, too) at varying stages of transformation by microbes, and animal feces. Feces were attributed to animal groups (epigeic and anecic earthworms, millipedes, enchytraeids, mites, insects) according to their sizes, shapes, and colors (Galvan et al., 2005). Only one category (69) was left unidentified. Mineral particles and assemblages, as well as animals (bodies, moults) were also included in the analysis. Miscellaneous humus components were plant debris not attributable to any plant parts (Category 41) or too transformed and without any recognizable plant or animal origin (Category 52).

The first four axes explained $11.4,10.2,7.9$, and $7.0 \%$ of the total variance, respectively (eigen values $0.49,0.44,0.34,0.3$ ). Although they explained only $36 \%$ of the total variance, the first four factorial axes allowed to discern clearly interpretable clusters in both $\mathrm{Oa}$ and $\mathrm{A}$ horizons, which was the criterion used for the detection of significant trends according to Benzécri (1969). The projection of categories of humus components in the plane of the first two axes (Fig. 2) displayed three branches, one corresponding to Oa horizons, the others to two different kinds of A horizons. Axis 1 reflected the opposition between $\mathrm{Oa}$ (positive side) to A (negative side) horizons. As expected, Oa horizons were characterized by organic feces (Categories 62, 65, 66, 68, and 70), bodies of epigeic animals (Categories 76 and 77) and numerous plant debris (Categories 1 to 41 , with a few exceptions), while A horizons were characterized by mineral-organic 


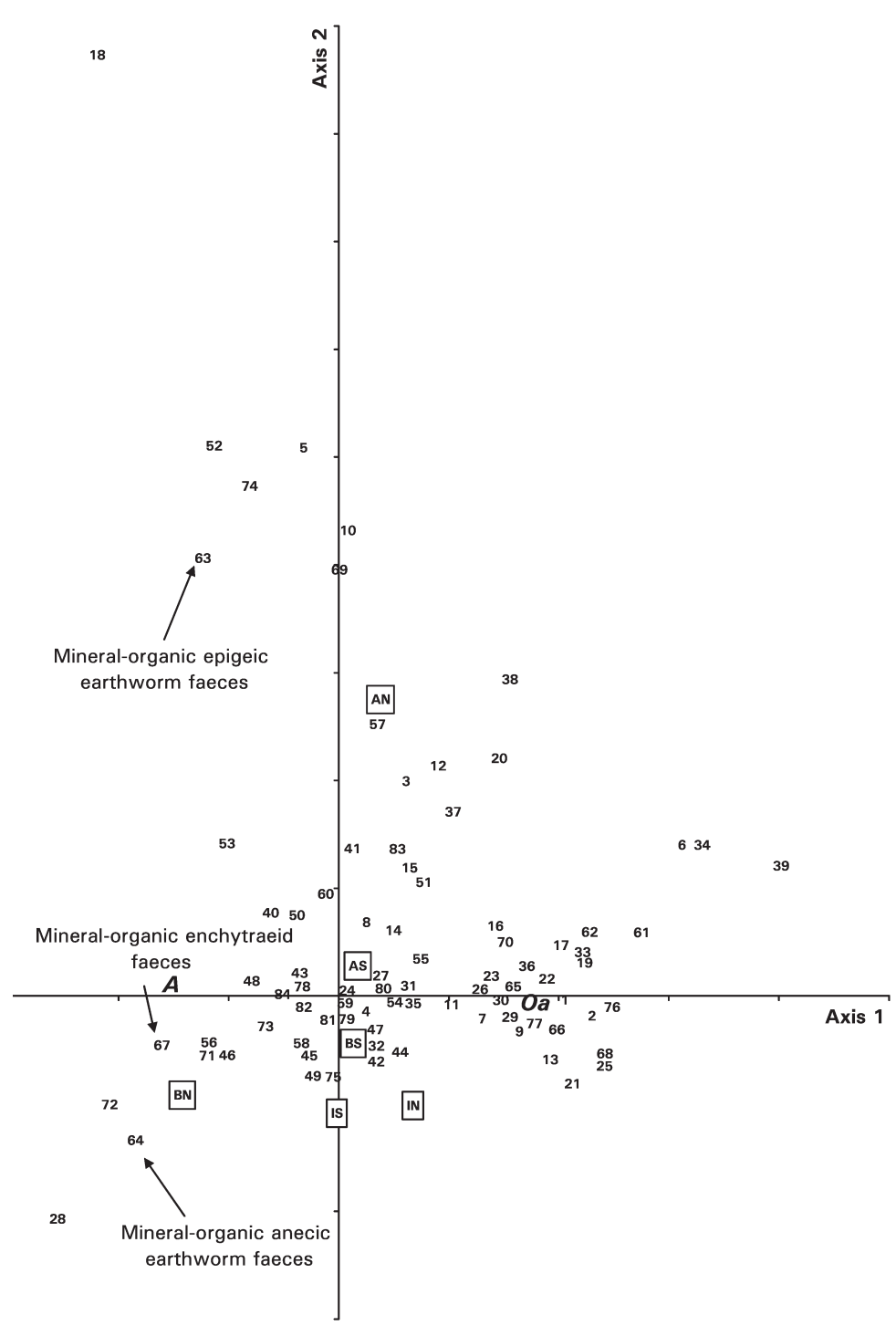

Fig. 2. Projection of the categories of humus components (main variables) in the plane of the first two axes of correspondence analysis, together with additional variables (horizons, sites). Most prominent animal feces in A horizons were arrowed

North (AN) and present (although as a minor part of the samples) in Acid South (AS).

The projection of the categories in the plane of Axes 1 and 3 (Fig. 4) showed the same clustering of $\mathrm{Oa}$ horizons on the positive side of Axis 1 (same as in Fig. 2), but now two categories of A horizons were separated along Axis 3, the one with mineral-organic enchytraeid feces (Category 67), on the positive side, the other with anecic earthworm feces (Category 64) on the other side. These two categories belonged to the same branch in the plane of Axes 1 and 2 (Fig. 2). The projection of layers in the plane of Axes 1 and 3 (Fig. 5) shows that A horizons with mineral-organic enchytraeid feces were mostly present in AS, but some horizons of this kind were also present, although less frequently, in AN and IS, and practically not in IN, BN, and BS. If we combine results from the first three axes, taking into account only the three main groups of mineral-organic feces (epigeic and anecic earthworms, enchytraeids), it appears that the A horizon of AN was mostly characterized by epigeic earthworm activity, whereas AS was mostly characterized by enchytraeid activity and the other sites by anecic earthworm activity, IS being in an intermediate position between AS and BN/BS.

While Axes 2 and 3 did not distinguish clusters within the Oa horizon, Axis 4 (Fig. 6) opposed Oa horizons with organic earthworm feces (projected on the positive side of this axis) to another cluster, characterized by organic enchytraeid and mite feces (projected on the negative side). The projection of layers (Fig. 7) showed that both clusters of Oa horizons were present in AN and AS, only the cluster with enchytraeid and mite activity was present in IN and IS, and poor differentiation (but rather on the earthworm side) occurred in BN and BS.

\section{Biotic Relationships between Oa and A Horizons}

We further investigated whether earthworm and

feces (Categories 63, 64, and 67), roots (Categories 42 to 51), and mineral particles (Categories 71 to 75 ). Axis 2 showed the contrast between two kinds of A horizons, the one (positive side) with mineral-organic epigeic earthworm feces (Category 63), the other (negative side) with anecic (all mineral-organic) earthworm feces (Category 64) and mineral-organic enchytraeid feces (Category 67). The projection of layers on the same two axes (Fig. 3) showed that the distinction between $\mathrm{Oa}$ and A horizons, as done by naked eye in the field as organic or mineral-organic, respectively, was fairly good, except in $\mathrm{BN}$ where most layers exhibited intermediary features (corresponding points were projected not far from the origin, indicating the paucity of characteristic features). A few A horizons had been misidentified as $\mathrm{Oa}$ horizons, in particular in AS. Conversely, a few Oa horizons had been misidentified as A horizons, in particular in AN. The two kinds of A horizons (with either anecic/enchytraeid or epigeic worm feces) were not equally distributed in the six sites. While A horizons with epigeic worm feces were absent from Intermediate North (IN), Intermediate South (IS) and near absent from Basic North (BN) and Basic South (BS), they were dominant in Acid enchytraeid activity occurred both in $\mathrm{Oa}$ and $\mathrm{A}$ horizons, or whether different animal groups were living in these horizons. The percentage volume of organic enchytraeid feces in the $\mathrm{Oa}$ horizon was positively correlated with that of mineral-organic feces of the same animal group in the corresponding A horizon $(r=0.50, P<0.0001)$. The correlation of organic enchytraeid feces in the Oa horizon with organic feces of the same animal group in the A horizon was insignificant $(r=0.11, P=0.26)$. The correlation of organic enchytraeid feces in the Oa horizon with mineral-organic epigeic earthworm feces in the A horizon was negative $(r=-0.36, P<0.001)$. Thus, Oa horizons with high enchytraeid activity (in the form of organic deposits) were associated with high enchytraeid activity (in the form of mineral-organic deposits) in the underlying A horizon. Similarly, organic epigeic earthworm feces in the Oa horizon were positively correlated with mineral-organic epigeic earthworm feces in the A horizon $(r=0.50, P<0.0001)$. Thus, the two kinds of Oa horizons that had been depicted by CA, the one dominated by enchytraeid activity and the other by earthworm activity, 
were associated with A horizons showing dominance of the same animal groups.

Although poorly represented in the studied layers (at most $2 \%$ of the matrix against $57 \%$ for organic enchytraeid feces), mite feces were positively correlated with organic enchytraeid feces $(r=$ $0.20, P<0.001$ ), indicating the coincidence of these two animal groups, with mites largely subordinate to the other animal group.

Anecic earthworm feces in the A horizon were positively correlated with the same category of feces in the overlying Oa horizon $(r=0.41, P<0.0001)$ and were negatively correlated with organic epigeic earthworm feces in the Oa horizon $(r=-0.22, P<0.05)$. Thus, anecic earthworm activity was concomitant in $\mathrm{Oa}$ and $\mathrm{A}$ horizons, but these animals deposit mineral-organic feces in both horizons, contrary to enchytraeids and epigeic earthworms, the feces of which were in agreement with the organic or mineral-organic nature of the horizon.

We further investigated whether the depth of the Oa horizon was related to biogenic structures. Organic enchytraeid feces exhibited by far the highest (and positive) correlation with depth of the Oa horizon $(r=0.42, P<0.0001)$. Thus, the thicker the Oa horizon, the more enchytraeid feces it contained.

\section{Influence of the Age of Trees on the Composition of $\mathrm{Oa}$ and $\mathrm{A}$ Horizons}

Mineral-organic enchytraeid feces in the A horizon exhibited a positive significant correlation with age of trees $(r=0.41, P<0.0001)$. Conversely, anecic earthworm feces in A horizons exhibited a negative significant correlation with age of trees $(r=-0.21, P<0.05)$. This points to a change in the balance between enchytraeid and anecic earthworm activity during stand development. The correlation between age of trees and depth of the Oa horizon was insignificant $(r=$ $0.06, P=0.51)$.

\section{DISCUSSION}

\section{Enchytraeid Activity and the Formation of Moder}

Correspondence analysis and correlation studies showed that a few distinct assemblages of $\mathrm{Oa}$ and $\mathrm{A}$ horizons were present in our study sites, and that each of them could be characterized by a particular kind of animal activity. Awaiting for experimental studies, it can be considered that the common occurrence of the same category of feces in both $\mathrm{Oa}$ and $\mathrm{A}$ horizons is an indirect evidence that the same organisms are involved in the building of their structures, according to the
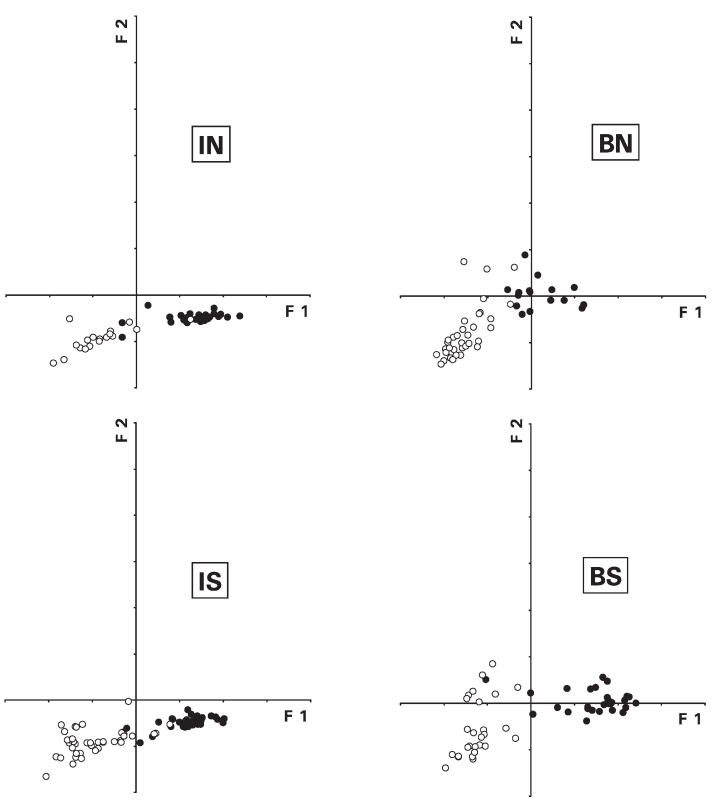

3. Projection of the samples in the plane of the first two axes of correspondence analysis. (black dots = Oa horizons, empty dots $=$ A horizons)

view stressed by Faber (1991) that the same species may exert different roles in different horizons. It can also be considered that the distribution of fecal categories reflected the activity of different animal groups. Oa horizons with high enchytraeid activity were associated with A horizons with high enchytraeid activity, too, although these animals deposited organic feces in

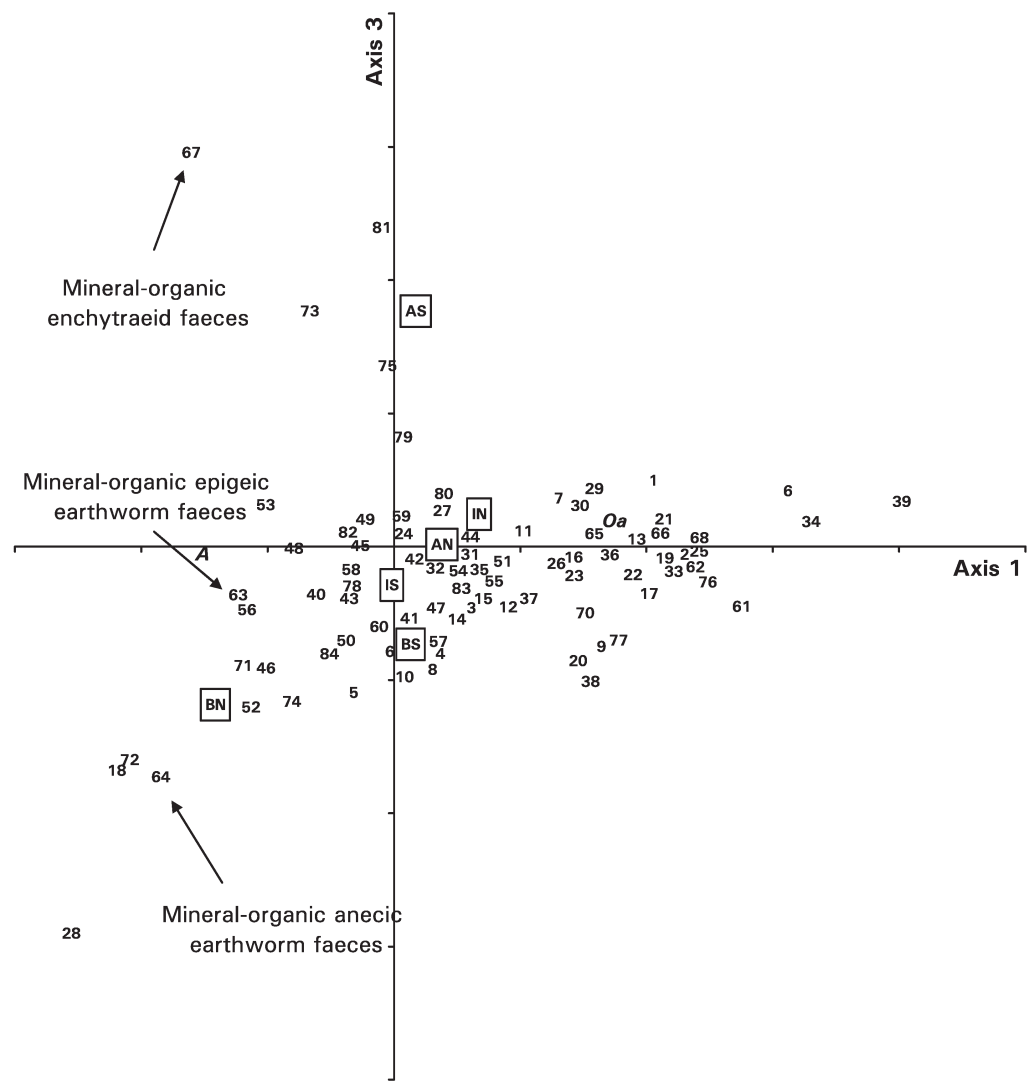

Fig. 4. Projection of the categories of humus components (main variables) in the plane of Axes 1 and 3 of correspondence analysis., together with additional variables (horizons, sites). Most prominent animal feces in A horizons were arrowed. 

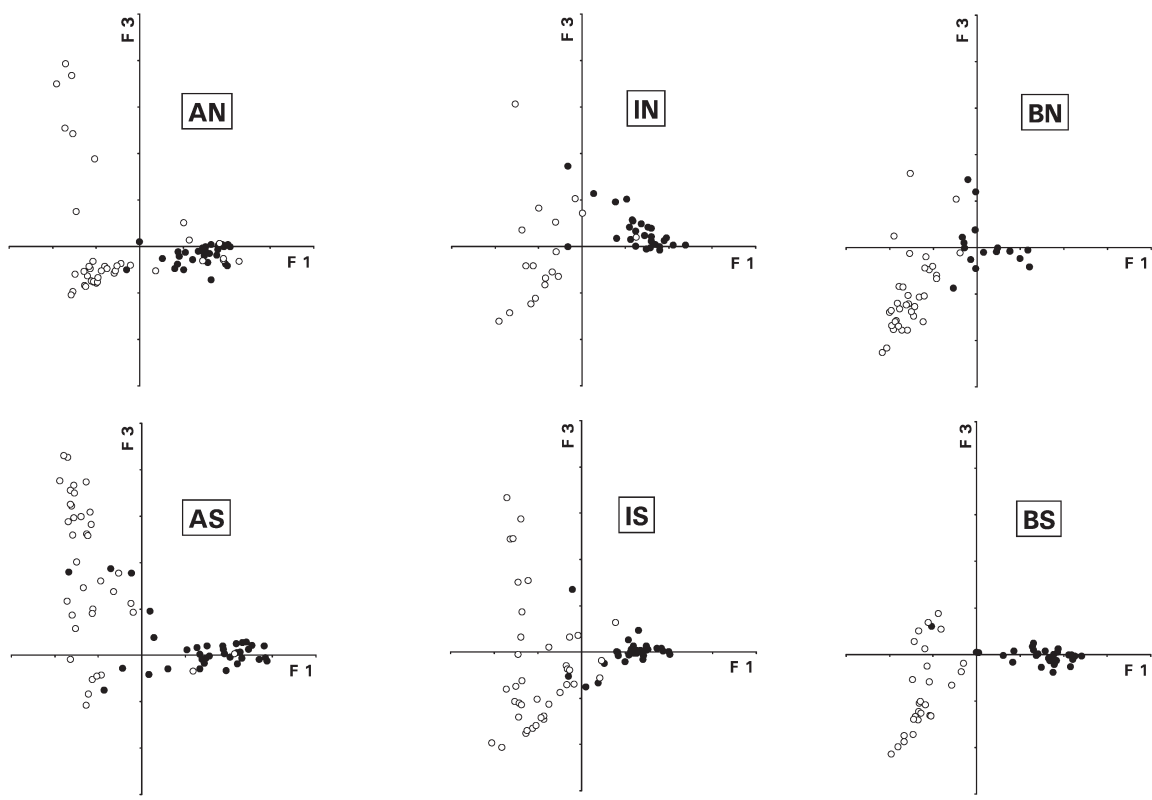

Fig. 5. Projection of the samples in the plane of Axes 1 and 3 of correspondence analysis. (black dots = Oa horizons, empty dots = A horizons).

the Oa horizons and mineral-organic feces in the underlying A horizons. Different species could be involved in this process but, as an animal group, these tiny annelid worms seem to characterize a dysmoder sensu Brêthes et al. (1995) or mormoder sensu Green et al. (1993), that is, a moder with a thick Oa horizon $(>1 \mathrm{~cm})$. Among our study sites, this humus form was absent on dolomitic substrates (BN, BS), but it was present from place to place on the more acidic substrates (Fig. 4-7). In the latter case, this points to a possible influence of overlying vegetation, if we consider the positive correlation between the amount of enchytraeid feces in the A horizon and the age of the trees at the sampling point. In their study of 13 beech forest stands growing under various environmental conditions, Ponge et al. (1997) showed that, among mesofaunal and macrofaunal invertebrates, enchytraeid worms were the dominant animal group in dysmoder. Other studies showed that enchytraeid worms create a microgranular structure (at the scale of 20 to $100 \mu \mathrm{m}$, not visible to the naked eye) in agricultural fields with poor earthworm activity (Didden, 1990; Van Vliet et al., 1993; Chan and Heenan, 1995) as well as in the A horizon of moder (Babel, 1968; Pawluk, 1987; Ponge, 1999b). Thus, these small annelids, known to ingest humified organic matter, pure or mixed with mineral matter (Ponge, 1991; Dawod and FitzPatrick, 1993), and to perform vertical movements over several centimeters (Springett et al., 1970), could be considered as mainly responsible for the continuous passage from an Oa to an A horizon, without any abrupt transition, which has been considered as a prominent feature of moder (Green et al., 1993; Ponge, 1999b). This contradicts the contention that the A horizon of moders, contrary to that of mulls, would be made of a side-by-side assemblage of organic and mineral matter, resulting from leachates of dissolved substances and suspended faunal droppings (Bal, 1970; Babel, 1975; Brêthes et al., 1995). This might hold for sandy or gravelly soils, where the size of mineral grains exceeds the silt size $(2-50 \mu \mathrm{m})$ required for their passage through an enchytraeid gut, as shown in soil sections by Zachariae (1965), but not for finergrained soils where these animals are able to mix organic matter with mineral matter (Didden, 1990; Topoliantz et al. 2000).

Regarding the increased role played by enchytraeid worms in $\mathrm{Oa}$ horizons of increasing thickness, some authors argued that enchytraeids did not play a significant part in the degradation of organic matter, and that their abundance could not contribute to the decomposition of litter nor to the mixing of organic matter with mineral matter (Zachariae, 1964; Toutain et al., 1982). The observations made by Ponge (1984, 1985, 1988) on Pinus sylvestris L. litter showed that these animals, in particular the acidophilic Cognettia sphagnetorum Vejd. ingested well-decayed coniferous needles but digested only the fungi they hosted, and that they consumed (and degraded in their guts) a great amount of mycorrhizal fungal hyphae. It has also been shown that enchytraeids increased the mineralization of $\mathrm{O}$ horizons by stimulating the microflora, if not overgrazed (Standen, 1978; Wolters, 1988; Briones et al., 1998). We suggest that these animals may find more food, and a moister environment in the organic matter accumulated in coniferous forests, especially when a rich fungus flora is present, which is the case in particular in moder humus forms (Ponge, 2003). This may also explain their dominance (as ascertained by fecal deposits) under older trees. In the course of time, the ectomycorrhizal root system of coniferous trees is known to densify (Persson, 1980), thus increasing the resource available for enchytraeids through the development of mycorrhizal flora. However, we showed that the amount of enchytraeid feces in the A horizon increased with the age of trees, to the detriment of anecic earthworm feces (a feature indicating a change from mull to moder), but without any relationship with the depth of the Oa horizon. This points to the existence of two kinds of Oa horizons, one associated with moders (and enchytraeid activity), the other with amphis (and earthworm activity)

The fact that mite feces seemed to be largely subordinate to enchytraeid feces should not be considered to reflect the respective population sizes of these animal groups. Oribatid mites are abundant in thick $\mathrm{O}$ horizons where they reach population sizes (but not biomasses) higher than those of enchytraeids (Petersen and Luxton, 1982; Hartmann et al., 1989; Ponge et al., 1997). However, Ponge (1991, 1999a) observed that enchytraeids ingested oribatid mite feces, where the reverse phenomenon was not recorded. We infer that in the course of time, and with increasing depth in the soil, mite feces are progressively replaced by enchytraeid feces even where both animal groups are present at similar densities.

\section{Earthworm Activity and the Formation of amphi}

If we disregard a few samples of mull, near all humus profiles sampled in the study transects belonged either to moder 
or to amphi humus forms. In the latter case, earthworm activity was prominent in both $\mathrm{Oa}$ and $\mathrm{A}$ horizons. However, the two ecological categories of earthworms we identified (anecic and epigeic earthworms) were not distributed equally among the sites, judging from the part played by their excrements in the composition of A horizons (Table 4). Epigeic earthworm activity was dominant in AN (Fig. 3), while anecic earthworm activity was dominant in BN and BS (Fig. 5), and enchytraeids and anecic earthworms were present in IN and IS (Fig. 3 and 5). It seems that two distinct forms of amphi were present in the study region, according to the presence or the absence of anecic earthworms (Table 4). A fine-grained structure in the A horizon (size of aggregates $<5 \mathrm{~mm}$ in diameter) is typical of epigeic earthworm activity, forming the Form 1, which is present in AN and AS, while anecic activity (even when epigeic earthworms are present) results in bigger aggregates (Galvan et al., 2005), forming the Form 2, which is present in BN, BS, IN, and IS.

We may wonder whether epigeic earthworms, known to live in litter, are able to mix organic matter with mineral matter in the same way as anecic earthworms do. Dendrobaena octaedra (Savigny) was the dominant epigeic species in our study sites (Guella, 2006, personal communication) and was near the only earthworm species living in AN, where all amphis were of the epigeic form. This small, slender acidophilic species (10-60 $\mathrm{mm}$, width $1 \mathrm{~mm}$ ) is known to feed not only on litter components, such as coniferous needles, but also on humified mineral matter, and to burrow in the mineral soil (Ponge, 1988). However, vertical distribution data differ according to authors. Abrahamsen (1972) never found it below $5 \mathrm{~cm}$ in Norwegian coniferous forest soils while Martinucci and Sala (1979), working not too far from our study sites (in the Venetian Alps) considered this species to be a weak burrower, which was also found in the mineral soil, especially in the fall.

\section{Moder versus Amphi and the Balance of Annelid Communities}

The difference between moders and amphis was depicted by a strong negative correlation between enchytraeid and epigeic earthworm feces. This could be ascribed to the competitive interactions that have been observed, first by co-occurrence data, second by laboratory experiments, between the lumbricid D. octaedra and the enchytraeid C. sphagnetorum (Huhta and Viberg, 1999), showing suppression of the enchytraeid population by earthworms. The growth of spruce may influence this balance in favor of the less nutrient-consuming animal group (enchytraeids) through an increase in the net nutrient uptake of trees, which impoverishes the soil (Miller, 1984). A reversal of this phenomenon in favor of the earthworm population has been observed under old trees ( $\sim 200 \mathrm{yr})$ in the French northern Alps (Bernier and Ponge, 1994; Ponge et al., 1998).

Our observations in different upper montane spruce forests of the Trentino revealed the gradual passage from moder to amphi humus forms, the former more typical for acid, the latter for basic domains (Table 4). Despite our lack of knowledge on the conditions favoring amphi, the role played by soil fauna in the building of this humus form can be established by the quantitative analysis of animal feces. Our results point to the need to reconsider and to precise the juxtaposition of mineral

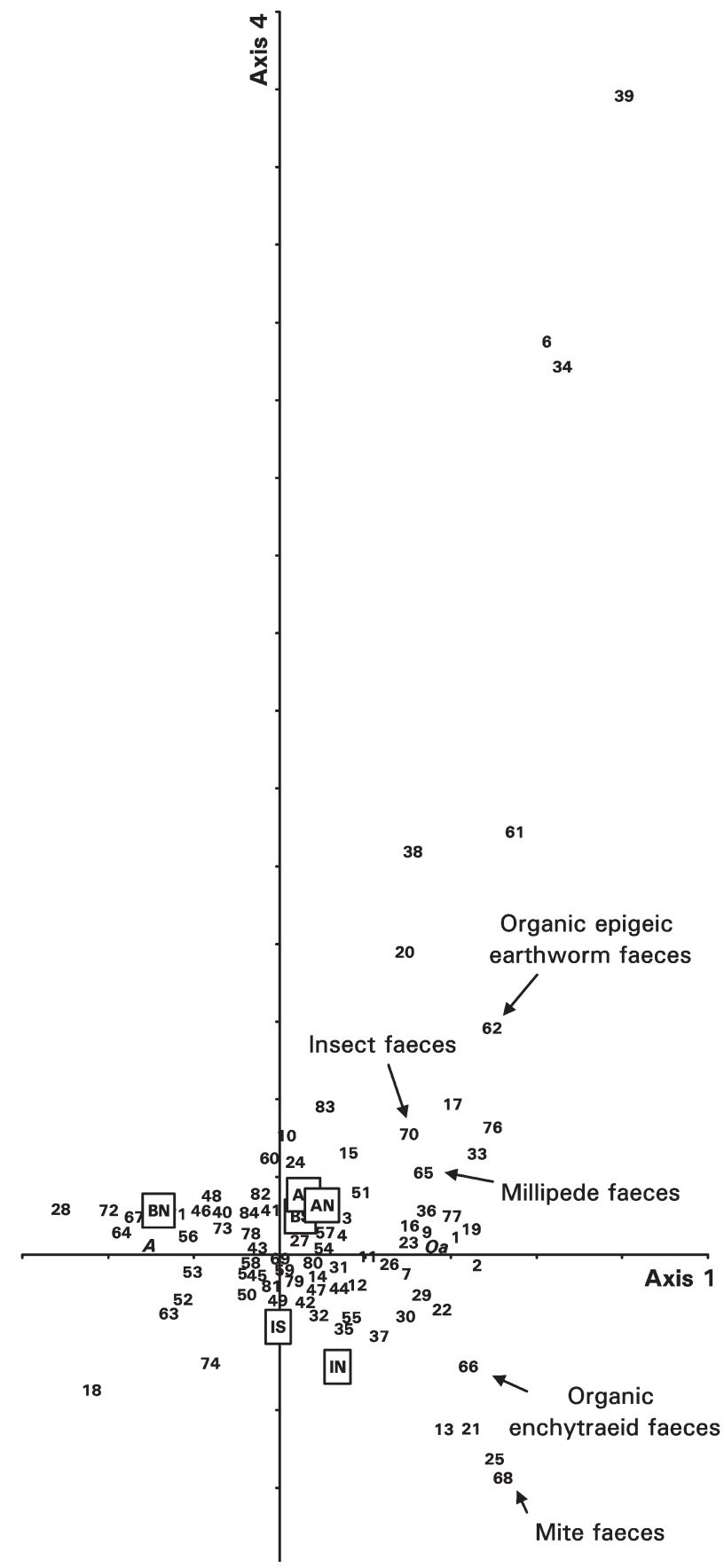

Fig. 6. Projection of the categories of humus components (main variables) in the plane of Axes 1 and 4 of correspondence analysis., together with additional variables (horizons, sites). Most prominent animal feces in Oa horizons were arrowed.

matter and organic matter in the A horizon as a diagnostic feature of moders (as opposed to mulls). We showed that the structure created by enchytraeid activity in the A horizon of moders was similar to that of earthworm mulls and amphis (i.e., a mixing of mineral and organic matter), but it was much finer. The widely reported assemblage of coarse mineral grains, covered or mixed with organic deposits, in moders, results more from the coarse texture of sandy soils (more prone to the formation of moders because of their poor nutrient availability) than from the absence of burrowing activity in the A horizon. Amphis differ from moders by the coarser grain of the structure in the A horizon (earthworm feces instead of enchy- 

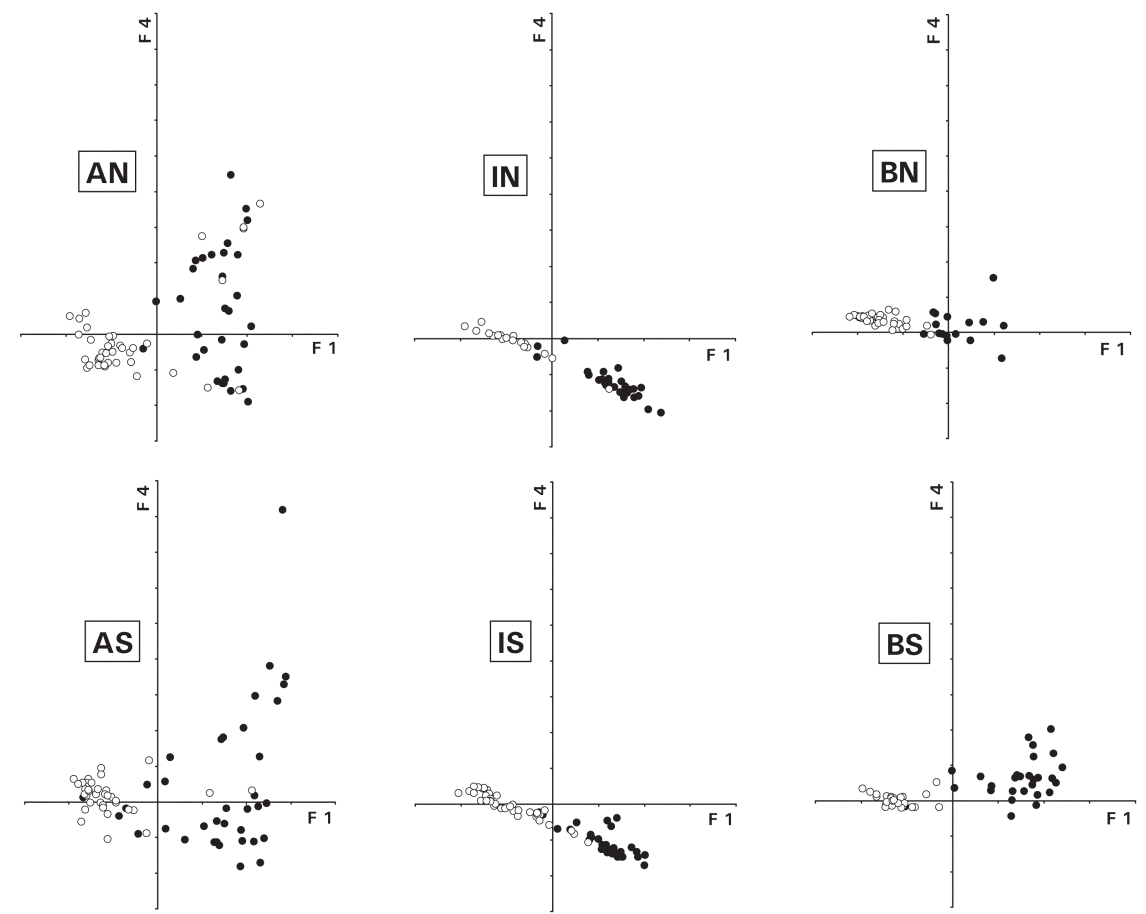

Fig. 7. Projection of the samples in the plane of Axes 1 and 4 of correspondence analysis. (black dots = Oa horizons, empty dots = A horizons).

traeid feces) but also in the Oa horizon, which is comprised of earthworm feces. In that sense, the Oa horizon of amphis does not differ from that of eumoders (Brêthes et al., 1995), which is thin $(\leq 1 \mathrm{~cm})$ and comprised of fecal pellets visible to the naked eye $(>100 \mu \mathrm{m})$.

Awaiting further observations and laboratory experiments, it can be hypothesized that the main difference between moders and amphis lies in the important part played by epigeic earthworms (compared with other macro-invertebrates) in the saprophagous community of the latter, combined with seasonal influences on their vertical distribution: earthworms are known to live deeper in the ground than most other litter-dwelling macro-invertebrates when the cold (or dry) season becomes unfavorable to epigeic activity (Schaefer, 1991).

Concerning the independence of $\mathrm{Oa}$ and $\mathrm{A}$ horizons, it can be concluded that they are inhabited by the same animal groups: when enchytraeid or earthworm activity is dominant in the A horizon, it also dominates in the Oa horizon. The same animal group (maybe the same species, not proved in the present study) ingests organic matter in $\mathrm{Oa}$ or a mixture of mineral and organic matter in A. This had been already shown to occur in moders in beech forests of Belgium (Ponge, 1999b). Reasons for the incomplete incorporation of organic matter (Oa horizon) within the A horizon of amphi is still a matter of conjecture, even though climatic reasons are highly probable, given its geographical location in European Alpine and Mediterranean régions.

\section{ACKNOWLEDGMENTS}

The authors are greatly indebted to the staff of the Centro Studi per l'Ambiente Alpino (Università di Padova), to Franco Previtali (Università degli Studi di Milano-Bicocca, Dipartimento di Scienze dell'Ambiente e del Territorio), to the staff of the Centro di Ecologia Alpina for commodities, technical help and free access to the sites, to Roberto Zampedri who gathered information about ecological features of the study sites, and to the Province of Trento for financial support (DINAMUS Project, decision $\mathrm{N}^{\circ}$ 437/2002) and grant given to the junior author.

\section{REFERENCES}

Abrahamsen, G. 1972. Ecological study of Lumbricidae (Oligochaeta) in Norwegian coniferous forest soils. Pedobiologia (Jena) 12:267-281.

Babel, U. 1968. Enchytraeen-Losungsgefuge in Löss. Geoderma 2:57-63.

Babel, U. 1975. Micromorphology of soil organic matter. p. 369-473. In J.E. Gieseking (ed.) Soil components. I. Organic components. Springer, Berlin, Germany.

Bal, L. 1970. Morphological investigation in two moder-humus profiles and the role of the soil fauna in their genesis. Geoderma 4:5-36.

Benzécri, J.P. 1969. Statistical analysis as a tool to make patterns emerge from the data. p. 35-74. In S. Watanabe (ed.) Methodologies of pattern recognition. Academic Press, New York.

Bernier, N. 1996. Altitudinal changes in humus form dynamics in a spruce forest at the montane level. Plant Soil 178:1-28.

Bernier, N., and J.F. Ponge. 1994. Humus form dynamics during the sylvogenetic cycle in a mountain spruce forest. Soil Biol. Biochem. 26:183-220.

Bernier, N., and J.F. Ponge. 1998. Lumbricus terrestris L. distribution within an experimental humus mosaic in a mountain spruce forest. Biol. Fertil. Soils 28:81-86.

Bernier, N., J.F. Ponge, and J. André. 1993. Comparative study of soil organic layers in two bilberry-spruce forest stands (Vaccinio-Piceetea). Relation to forest dynamics. Geoderma 59:89-108.

Brêthes, A., J.J. Brun, B. Jabiol, J.F. Ponge, and F. Toutain. 1995. Classification of forest humus forms: A French proposal. Ann. Sci. For. 52:535-546.

Bridges, E.M., N.H. Batjes, and F.O. Nachtergaele. 1998. World reference base for soil resources. ISRIC, FAO, ISSS, Leuven, Belgium.

Table 4. Dominant humus forms and biogenic structures in the six study sites.

\begin{tabular}{|c|c|c|c|c|c|c|}
\hline Site codes & AN & AS & IN & IS & BN & BS \\
\hline Dominant humus forms & moder, amphi 1 & moder, amphi 1 & amphi 2, moder & amphi 2, moder & amphi 2 & amphi 2 \\
\hline Fecal deposits in Oa horizon & & & & & & \\
\hline epigeic earthworms & + & + & nil & nil & $\neq$ & $\neq$ \\
\hline enchytraeids and mites & $\dagger$ & $t$ & $\neq$ & $\neq$ & $\S$ & $\S$ \\
\hline Fecal deposits in A horizon & & & & & & \\
\hline anecic earthworms & nil & $\S$ & $\neq$ & $\neq$ & $\neq$ & $\neq$ \\
\hline epigeic earthworms & $\neq$ & + & nil & nil & $\S$ & $\S$ \\
\hline enchytraeids & $t$ & $\neq$ & $\S$ & $t$ & $\S$ & $\S$ \\
\hline
\end{tabular}

t abundant

‡ very abundant

$\S$ few 
Briones, M.J.I., J. Carreira, and P. Ineson. 1998. Cognettia sphagnetorum (Enchytraeidae) and nutrient cycling in organic soils: A microcosm experiment. Appl. Soil Ecol. 9:289-294.

Chan, K.Y., and D.P. Heenan. 1995. Occurrence of enchytraeid worms and some properties of their casts in an Australian soil under cropping. Aust. J. Soil Res. 33:651-657.

Chauvat, M., J.F. Ponge, and V. Wolters. 2007. Humus structure during a spruce forest rotation: Quantitative changes and relationship to soil biota. Eur. J. Soil Sci. 58:625-631.

Dawod, V., and E.A. FitzPatrick. 1993. Some population sizes and effects of the Enchytraeidae (Oligochaeta) on soil structure in a selection of Scottish soils. Geoderma 56:173-178.

Didden, W.A.M. 1990. Involvement of Enchytraeidae (Oligochaeta) in soil structure evolution in agricultural fields. Biol. Fertil. Soils 9:152-158.

Faber, J.H. 1991. Functional classification of soil fauna: A new approach. Oikos 62:110-117.

Galvan, P., L. Scattolin, J.F. Ponge, F. Viola, and A. Zanella. 2005. Le forme di humus e la pedofauna. Interpretazione delle interrelazioni e chiavi di riconoscimento. (In Italian). Sherwood 112:33-39.

Graefe, U., and A. Beylich. 2006. Humus forms as tool for upscaling soil biodiversity data to landscape level? Mitteilgn. Dtsch. Bodenkundl. Gesellsch. 108:6-7.

Green, R.N., R.L. Trowbridge, and K. Klinka. 1993. Towards a taxonomic classification of humus forms. For. Sci. Monogr. 29:1-49.

Greenacre, M.J. 1984. Theory and applications of correspondence analysis. Academic Press, London.

Hartmann, P., M. Scheitler, and R. Fischer. 1989. Soil fauna comparisons in healthy and declining Norway spruce stands. p. 137-150. In E.D. Schulze et al. (ed.) Forest decline and air pollution. Springer, Berlin, Germany.

Huhta, V., and K. Viberg. 1999. Competitive interactions between the earthworm Dendrobaena octaedra and the enchytraeid Cognettia sphagnetorum. Pedobiologia (Jena) 43:886-890.

Jabiol, B., A. Zanella, M. Englisch, H. Hager, K. Katzensteiner, and R.W. de Waal. 2004. Towards an European classification of terrestrial humus forms. Eurosoil Congress, Freiburg, September 2004.

Jongerius, A. 1963. Optic-volumetric measurements on some humus forms. p. 137-148. In J. Doeksen and J. Van der Drift (ed.) Soil organisms. NorthHolland Publishing Co., Amsterdam, The Netherlands.

Loranger, G., J.F. Ponge, and P. Lavelle. 2003. Humus forms in two secondary semi-evergreen tropical forests. Eur. J. Soil Sci. 54:17-24.

Martinucci, G., and G. Sala. 1979. Lumbricids and soil types in prealpine and alpine woods. Boll. Zool. 46:279-297.

Miller, H.G. 1984. Dynamics of nutrient cycling in plantation ecosystems. p. 53-78. In G.D. Bowen and E.K.S. Nambiar (ed.) Nutrition of forest trees in plantations. Academic Press, London.

Nihlgård, B. 1971. Pedological influence of spruce planted on former beech forest soils in Scania, South Sweden. Oikos 22:302-314.

Nilsson, S.I., H.G. Miller, and J.D. Miller. 1982. Forest growth as a possible cause of soil and water acidification: An examination of the concepts. Oikos 39:40-49.

Odasso, M. 2002. I tipi forestali del Trentino. Catalogo, guida al riconoscimento, localizzazione e caratteristiche ecologico-vegetazionali. (In Italian). Rep. Centr. Ecol. Alp. 25:1-192.

Ovington, J.D. 1954. Studies of the development of woodland conditions under different trees. II. The forest floor. J. Ecol. 42:71-80.

Pawluk, S. 1987. Faunal micromorphological features in moder humus of some Western Canadian soils. Geoderma 40:3-16.

Persson, H. 1980. Death and replacement of fine roots in a mature Scots pine stand. Ecol. Bull. 32:251-260.

Petersen, H., and M. Luxton. 1982. A comparative analysis of soil fauna populations and their role in decomposition processes. Oikos 39:287-388.

Pickett, S.T.A. 1989. Space-for-time substitution as an alternative to long term studies. p. 110-135. In G.E. Likens (ed.) Long term studies in ecology. Springer, New York.

Ponge, J.F. 1984. Étude écologique d'un humus forestier par l'observation d'un petit volume, premiers résultats. I. La couche $\mathrm{L}_{1}$ d'un moder sous pin sylvestre. (In French). Rev. Ecol. Biol. Sol 21:161-187.
Ponge, J.F. 1985. Étude écologique d'un humus forestier par l'observation d'un petit volume. II. La couche $\mathrm{L}_{2}$ d'un moder sous Pinus sylvestris. (In French). Pedobiologia (Jena) 28:73-114.

Ponge, J.F. 1988. Étude écologique d'un humus forestier par l'observation d'un petit volume. III. La couche $\mathrm{F}_{1}$ d'un moder sous Pinus sylvestris. (In French). Pedobiologia (Jena) 31:1-64.

Ponge, J.F. 1991. Food resources and diets of soil animals in a small area of Scots pine litter. Geoderma 49:33-62.

Ponge, J.F. 1999a. Heterogeneity in soil animal communities and the development of humus forms. p. 33-44. In N. Rastin and J. Bauhus (ed.) Going underground. Ecological studies in forest soils. Research Signpost, Trivendrum, India.

Ponge, J.F. 1999b. Horizons and humus forms in beech forests of the Belgian Ardennes. Soil Sci. Soc. Am. J. 63:1888-1901.

Ponge, J.F. 2003. Humus forms in terrestrial ecosystems: A framework to biodiversity. Soil Biol. Biochem. 35:935-945.

Ponge, J.F., J. André, O. Zackrisson, N. Bernier, M.C. Nilsson, and C. Gallet. 1998. The forest regenration puzzle: Biological mechanisms in humus layer and forest vegetation dynamics. Bioscience 48:523-530.

Ponge, J.F., P. Arpin, F. Sondag, and F. Delecour. 1997. Soil fauna and site assessment in beech stands of the Belgian Ardennes. Can. J. For. Res. 27:2053-2064

Ponge, J.F., R. Chevalier, and P. Loussot. 2002. Humus Index: An integrated tool for the assessment of forest floor and topsoil properties. Soil Sci. Soc. Am. J. 66:1996-2001.

Sadaka, N., and J.F. Ponge. 2003. Climatic effects on soil trophic networks and the resulting humus profiles in holm oak (Quercus rotundifolia) forests in the High Atlas of Morocco as revealed by correspondence analysis. Eur. J. Soil Sci. 54:767-777.

Sagot, C., J.J. Brun, J.L. Grossi, J.H. Chauchat, and G. Boudin. 1999. Earthworm distribution and humus forms in the development of a seminatural alpine spruce forest. Eur. J. Soil Biol. 35:163-169.

Schaefer, M. 1991. The animal community: Diversity and resources. p. 51-120. In E. Röhrig and B. Ulrich (ed.) Ecoystems of the world. VII. Temperate deciduous forests. Elsevier, Amsterdam, The Netherlands.

Schaetzl, R.J., and S. Anderson. 2005. Soils, genesis and geomorphology. Cambridge Univ. Press, Cambridge, UK.

Scotti, I., G.G. Vendramin, L.S. Matteotti, C. Scarponi, M. Sari-Gorla, and G. Binelli. 2000. Postglacial recolonization routes for Picea abies K. in Italy as suggested by the analysis of sequence-characterized amplified region (SCAR) markers. Mol. Ecol. 9:699-708.

Sokal, R.R., and F.J. Rohlf. 1995. Biometry, 3rd ed. Freeman, New York.

Springett, J.A., J.E. Brittain, and B.P. Springett. 1970. Vertical movement of Enchytraeidae (Oligochaeta) in moorland soils. Oikos 21:16-21.

Standen, V. 1978. The influence of soil fauna on decomposition by microorganisms in blanket bog litter. J. Anim. Ecol. 47:25-38.

Topoliantz, S., J.F. Ponge, and P. Viaux. 2000. Earthworm and enchytraeid activity under different arable farming systems, as exemplified by biogenic structures. Plant Soil 225:39-51.

Toutain, F., G. Villemin, A. Albrecht, and O. Reisinger. 1982. Étude ultrastructurale des processus de biodégradation. II. Modèle enchytréideslitière de feuillus. Pedobiologia (Jena) 23:145-156.

Ulrich, B. 1994. Process hierarchy in forest ecosystems: An integrative ecosystem theory. p. 353-397. In A. Hutterman and D. Godbold (ed.) Effects of acid rain on forest processes. Wiley-Liss, New York.

Van Vliet, P.C.J., L.T. West, P.F. Hendrix, and D.C. Coleman. 1993. The influence of Enchytraeidae (Oligochaeta) on the soil porosity of small microscosms. Geoderma 56:287-299.

Vetter, M., C. Wirth, H. Böttcher, G. Churkina, E.D. Schulze, T. Wutzler, and G. Weber. 2005. Partitioning direct and indirect human-induced effects on carbon sequestration of managed coniferous forests using model simulations and forest inventories. Glob. Change Biol. 11:810-827.

West, T.S. 1969. Complexometry with EDTA and related reagents, 3rd ed. BDH Chemicals Ltd., Poole, Dorset, UK.

Wolters, V. 1988. Effects of Mesenchytraeus glandulosus (Oligochaeta, Enchytraeidae) on decomposition processes. Pedobiologia (Jena) 32:387-398.

Zachariae, G. 1964. Welche Bedeutung haben Enchytraeen im Waldböden? p. 